\title{
PENGUNGKAPAN MODAL INTELEKTUAL: FAKTOR PENENTU DAN KONSEKUENSINYA PADA NILAI PERUSAHAAN
}

\author{
I Gusti Ngurah Agung Suaryana ${ }^{1}$ \\ ${ }^{1}$ Fakultas Ekonomi dan Bisnis, Universitas Udayana, Indonesia \\ e-mail:agungsuaryana@unud.ac.id
}

\section{ARTICLE INFO}

Keywords :

Intellectual Capital Disclosure ; Company Value ; Board of Commissioners ; Company Size.

How to cite :

Ngurah Agung Suaryana, I Gusti., (2019). Pengungkapan Modal Intelektual : Faktor Penentu dan Konsekuensinya Pada Nilai Perusahaan. JMM UNRAM, 8(3), $311-326$

DOI :

http://dx.doi.org/10.29303/jmm.v8i3.493

$\begin{array}{ll}\text { Dikumpulkan } & : \text { 01 September } 2019 \\ \text { Direvisi } & : 19 \text { September } 2019 \\ \text { Dipublikasi } & : 23 \text { September } 2019\end{array}$

\begin{abstract}
Intellectual capital is a knowledge-based resource that plays an important role in creating a sustainable competitive advantage of a company. Intellectual capital is an important resource in the era of information and knowledge for company growth. Intellectual capital as an important resource owned by the company needs to be disclosed by the company to investors and potential investors. Disclosure of intellectual capital in Indonesia is still voluntary, it has been implicitly regulated in PSAK No. 19. This research will examine the determinants of intellectual capital disclosures and their consequences on company value. The determining factor that is suspected to affect the disclosure of intellectual capital in Indonesia is the number of board of commissioners, the proportion of independent board of commissioners, company size, and leverage. The consequence of intellectual capital disclosure is the value of the company. The study population was all companies included in the LQ45 on the Indonesia Stock Exchange in the period 2014 to 2016. The number of research samples was 135 observations. The analysis used is multiple linear regression. The results of this study found the number of board of commissioners, the proportion of independent board of commissioners, company size, and leverage had a positive effect on the disclosure of intellectual capital. The broader disclosure of intellectual capital, the higher the value of the company.

Modal Intelektual merupakan sumber daya berbasis pengetahuan yang beperan penting dalam menciptakan keunggulan kompetitif berkelanjutan perusahaan. Modal intelektual manjadi sumber daya penting pada era informasi dan pengetahuan untuk pertumbuhan perusahaan.Modal intelektual sebagai sumberdaya penting yang dimiliki oleh perusahaan perlu diungkapkan oleh perusahaan kepada investor dan calon investor. Pengungkapan modal intelektual di Indonesia masih bersifat sukarela, secara implisit telah diatur di
\end{abstract}




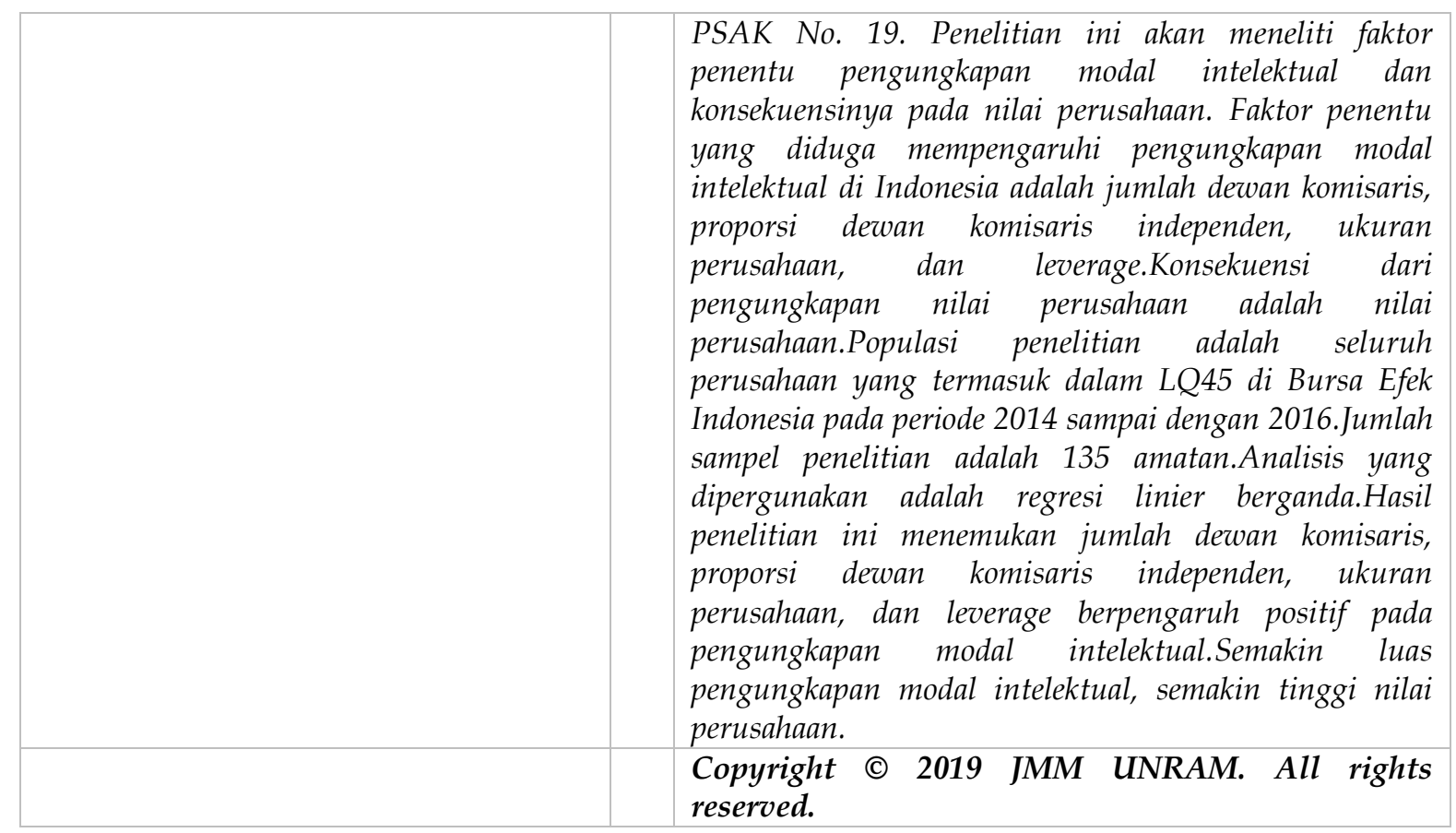

\section{PENDAHULUAN}

Modal intelektual manjadi sumber daya penting pada era informasi dan pengetahuan untuk pertumbuhan perusahaan. Basis pertumbuhan perusahaan beralih dari sumber daya berujud menjadi tidak berujud, yaitu modal intelektual (Guthrie et al., 1999).Faktor pendorong pertumbuhan perusahaan tidak hanya bersumber dari investasi fisik, seperti bangunan, masih, dan peralatan, namun bersumber dari pengetahuan sebagai sumberdaya kunci dalam perekonomian dan faktor produksi penting.Modal intelektual merupakan sumber daya penting dalam mendapatkan keunggulan kompetitif yang berkelanjutan (Hayton, 2005), menciptakan nilai dan meningkatkan kinerja dan pertumbuhan perusahaan (Ishak et al., 2016). Peran penting modal intelektual dalam perusahaan menjadi topik penting penelitian, seperti Abdolmohmmadi (2005), Bruggen dan Dao (2009), Octama (2011), Ulum et al. (2012), Rashid et al. (2012), Puteri dan Chairi (2016), Ramanauskaite dan Laginauskaite (2014), namun masih belum terdapat adanya konsistensi atas hasil yang ada.

Purnomosidhi (2005) mengungkapkan empat alasan penelitian tentang praktik pengungkapan modal intelektual perlu dilakukan dalam konteks Indonesia.Pertama, pemerintah terus membuat inovasi kebijakan dalam rangka mendorong terjapainya target investasi berupa pemotongan $\mathrm{PPh}$ Badan bagi perusahaan yang melakukan penelitian dan pengembangan.Pemerintah memberikan insentif untuk mendorong perusahaan melakukan peneliitan dan pengembangan, meningkatkan kesadaran perusahaan terhadap pentingnya modal intelektual dan pengungkapan sukarela modal intelektual.Kedua, pengungkapan modal intelektual merupakan salah satu dari 10 jenis informasi yang dibutuhkan pemakai.Ketiga, pengungkapan yang diwajib oleh profesi akuntansi terkait dengan modal fisik, namun modal intelektual belum wajib diungkapkan oleh perusahaan.Keempat, daya saing perusahaan Indonesia masih rendah kerena rendahnya produktivitas sumber daya manusia.

Modal intelektual sebagai sumberdaya penting yang dimiliki oleh perusahaan perlu diungkapkan oleh perusahaan kepada investor dan calon investor. Pengungkapan modal intelektual di Indonesia masih bersifat sukarela, secara implisit telah diatur di PSAK No. 
19. Penelitian ini akan meneliti faktor penentu pengungkapan modal intelektual dan konsekuensinya pada nilai perusahaan. Penelitian dilakukan pada perusahaan LQ 45 yang terdaftar di Bursa Efek Indonesia pada periode 2014 sampai dengan 2016.

Faktor penentu yang diduga mempengaruhi pengungkapan modal intelektual di Indonesia adalah ukuran dewan komisaris, dewan komisaris independen, tipe auditor, leverage, dan ukuran perusahaan. Variabel penjelas pengungkapan modal intelektual didasarkan pada teori keagenan (Jensen dan Meckling, 1976) dan teori legitimasi (Neysi et al., 2012).Teori keagenan menyatakan adanya upaya dari pihak agen untuk memberikan informasi secara sukarela kepada pihak prinsipal untuk memperoleh kepercayaan.Pengungkapan modal intelektual merupakan informasi sukarela yang diberikan oleh agen kepada prinsipal.Pengungkapan informasi modal intelektual secara sukarela oleh perusahaan ke investor atau calon investor untuk mengurangi asimetri informasi antara manajemen dan investor. Pengurangi asimetri informasi akan meningkatkan nilai perusahaan. Teori legitimasi menjelaskan bahwa perusahaan akan beroperasi dalam batasan dan norma yang dipersepsikan akan dilegitimasi oleh pemangku kepentingan (Guthrie et al., 2006; Ishak et al., 2016). Konsekuensi dari teori legitimasi adalah perusahaan akan mengungkapkan informasi secara sukarela untuk mendapatkan legitimasi dari stakeholders. Teori sinyal menduga pengungkapan informasi modal intelektual diharapkan meningkatkan nilai perusahaan. Peningkatkan tingkat pengungkapan modal intelektual menghasilkan penurunan kesalahan penilaian dari harga saham, sehingga meningkatkan nilai perusahaan.

\section{KAJIAN PUSTAKA}

\subsection{Pengaruh Ukuran Dewan Komisaris Terhadap Pengungkapan Modal Intelektual}

Dewan komisaris memegang peranan penting bagi perusahaan dalam melakukan pengawasan atas manajemen perusahaan.Cerboni dan Parbonetti (2007) mengungkap bahwa ukuran dewan komisaris berbanding terbalik dengan kualitas pengawasan sehingga pengungkapan informasi yang dilakukan perusahaan menjadi berkurang.Ditambahkan pula, bahwa semakin banyak jumlah anggota dewan maka menyebabkan adanya masalah komunikasi dan koordinasi, sehingga hal tersebut dapat menurunkan kemampuan dewan komisaris dalam melakukan pengawasan dan berdampak pada masalah agensi.Pengungkapan modal intelektual merupakan suatu bentuk pengungkapan sukarela yang dilakukan perusahaan untuk menyampaikan informasi terkait modal intelektual yang dimiliki.Penelitian Rashid (2012) berhasil membuktikan adanya pengaruh antara ukuran dewan dengan PMI.Semakin besar ukuran dewan justru membuat perusahaan melakukan pengungkapan modal intelektual lebih rendah, karena didasarkan menurunnya efektifitas dan koordinasi antar anggota dewan. Berdasarkan alur logis pemikiran di atas, dapat dirumuskan hipotesis pertama sebagai berikut :

H1. Ukuran dewan komisaris berpengaruh negatif terhadap pengungkapan modal intelektual.

\subsection{Pengaruh Dewan Komisaris Independen Terhadap PMI}

Dewan komisaris bertindak sebagai principal yang melakukan pengawasan pada agen. Dengan semakin besarnya proporsi dewan independen, maka dapat menjamin pemisahan antara prinsipal dengan keputusan manajemen perusahaan (Fama dan Jensen,1983). Dewan non independen memiliki kecenderungan untuk memihak manajemen perusahaan karena adanya hubungan kekerabatan mereka dengan manajemen perusahaan, sehingga dewan independen dipandang dapat menjadi mediator yang 
menjaga kepentingan pemegang saham dalam keputusan manajemen (Fama, 1980).Keberadaan dewan independen dianggap dapat meningkatkan pengungkapan informasi sukarela secara ekstensif (Cerbioni dan Parbonetti, 2007).

Hasil penelitian Chen dan Jaggi (2000), White et al. (2007) dan Rashid et al (2012) menunjukkan hasil yang serupa dan semakin memperkuat adanya pengaruh antara dewan komisaris independen terhadap pengungkapan modal intelektual. Semakin besar proporsi dewan komisaris maka akan membuat perusahaan melakukan pengungkapan secara lebih luas, karena dewan komisaris independen akan menjamin pemisahan kontrol dengan keputusan manajemen perusahaan. Oleh karena itu, dalam penelitian ini dirumuskan hipotesis kedua sebagai berikut.

H2. Dewan komisaris independen berpengaruh positif terhadap pengungkapan modal intelektual.

\subsection{Pengaruh Ukuran Perusahaan Terhadap Pengungkapan Modal Intelektual}

Perusahaan berukuran besar memiliki masalah agensi yang lebih kompleks dan perhatian dari stakeholders.Dalam rangka meminimalisir asimetri informasi tersebut, perusahaan membutuhkan biaya agensi dalam usahanya.sehingga untuk semakin mengurangi biaya agensi, perusahaan berukuran besar cenderung mengungkapkan informasi secara lebih luas (White et al, 2007; Ferreira, 2012). Perusahaan juga bersaha untuk mendapatkan legitimasi dari stakeholders dengan cara mengungkapkan informasi modal intelektual. Dengan pengungkapan yang dilakukan perusahaan maka biaya agensi tersebut dapat ditekan dan legitimasi dari stakeholdersakan diperoleh, sehingga berpengaruh pada keterbukaan informasi. Hal ini sesuai dengan teori keagenanyang menyatakan bahwa biaya agensi yang harus ditanggung perusahaan besar jauh lebih besar dibanding dengan perusahaan yang lebih kecil sehingga untuk menurunkan biaya tersebut, perusahaan perlu mengungkapkan informasi yang lebih banyak (Purnomosidhi, 2005). Sesuai dengan penelitian sebelumnya yang menunjukkan bahwa terdapat hubungan secara langsung antara ukuran perusahaan dengan PMI (Bozzolan et al., 2003; White et al , 2007; Cerbioni and Parbonetti, 2007; Cordazzo, 2007; Garcia-Meca et al., 2005, Garcia-Meca and Martinez, 2007; Guthrie et al., 2006; Oliveira et al., 2006; Octama, 2011; Ulum et al, 2012) dan alur pemikiran logis di atas, maka dirumuskan hipotesis keempat dalam penelitian yaitu semakin besar ukuran perusahaan maka semakin tinggi tingkat pengungkapan modal intelektual.

H3. Ukuran perusahaan berpengaruh positif terhadap pengungkapan modal intelektual

\subsection{Pengaruh Leverage Terhadap Pengungkapan Modal Intelektual}

Leverage menunjukkan tingkat ketergantungan penggunaan dana dari kreditur dalam rangka melakukan pembiayaan aset perusahaan (Utomo, 2015). Ketika perusahaan memiliki leverage yang tinggi maka akan meningkatkan ketertarikan dalam mengobservasi pasar modal, hal ini akan membuat perusahaan dengan mudah mengungkapkan informasi dalam rangka mengurangi biaya modal (Jensen dan Meckling, 1976; Rashid, 2012). Tingginya leverage dapat menyebabkan masalah keagenan. Untuk mengatasi masalah tersebut, dibutuhkan adanya biaya keagenan.Dalam rangka mengurangi biaya keagenan tersebut manajemen perusahaan mengungkapkan informasi tentang modal intelektual lebih luas. Hal ini didukung dengan hasil penelitian Williams (2001), Oliviera et al. (2006), Singh dan van der Zahn (2007), White et al. (2007), Ulum et al. (2012), dan Rashid et al. (2012) yang menunjukkan adanya hubungan yang signifikan dan positif antara leverage dengan pengungkapan modal intelektual. Berdasarkan berbagai pemikiran yang telah dibahas, maka dalam penelitian ini dapat dirumuskkan hipotesis keenam sebagai 
Berikut.

H4. Leverage berpengaruh positif terhadap PMI.

\subsection{Pengaruh PMI Terhadap Nilai Perusahaan}

PMI merupakan salah satu bentuk pengungkan sukarela yang lakukan oleh manajemen kepada investor atau calon investor perusahaan. Penelitian sebelumnya pada umumnya memanfaatkan teori sinyal untuk menjelaskan mengapa perusahaan mengungkapkan informasi sukarela kepada investor dan calon investor (Anam et al., 2011; Gordon et al., 2010). Teori sinyal dimaksudkan bahwa suatu organisasi akan berusaha untuk memberi sinyal berita baik kepada investor dan stakeholder lain melalui pengungkapan sukarela (Oliviera et al., 2006). Menurut Francis dan Schipper (1999), relevansi nilai diukur melalui kemampuan informasi laporan keuangan untuk menangkap atau merangkum informasi yang mempengaruhi nilai saham. Peningkatkan tingkat pengungkapan menghasilkan penurunan kesalahan penilaian dari harga saham, dengan demikian, meningkatkan kapitalisasi pasar perusahaan (Anam et al., 2011). Anam et al. (2011) menemukan hubungan positif antara pengungkapan modal intelektual dan nilai pasar berdasarkan teori sumber daya dan teori sinyal. Perusahaan memiliki sumber daya yang bernilai dan menciptakan nilai, mereka akan mengizinkan stakeholder mengetahui hal ini dengan mengungkapkan informasi. Lebih jauh, manajer juga akan bersedia untuk memberi sinyal proses penciptaan nilai kepada stakeholder, sehingga hipotesis dikembangkan sebagai berikut.

H5. Pengungkapan modal intelektual berpengaruh positif terhadap nilai perusahaan.

\section{METODE PENELITIAN}

\subsection{Lokasi Penelitian}

Lokasi penelitian ini adalah Bursa Efek Indonesia (BEI) yang menyediakan informasi laporan keuangan perusahaan dengan mengakses situs resmi BEI yaitu www.idx.co.id. Alasan memilih lokasi penelitian tersebut karena perusahaan - perusahaan yang terdaftar di BEI melaporkan laporan keuangan secara lengkap.

\subsection{Objek Penelitian}

Objek penelitian adalah suatu sifat dari objek yang ditetapkan oleh peneliti untuk dipelajari dan kemudian memperoleh simpulan (Sugiyono, 2016:39). Objek dari penelitian ini yaitu pengungkapan modal intelektual yang dilakukan oleh perusahaan LQ45 yang terdaftar di BEI pada tahun 2014-2016, di mana praktik pengungkapan modal intelektual tersebut dapat dipengaruhi oleh ukuran dewan komisaris, komisaris independen, ukuran perusahaan, leverage, dan tipe auditor. Pengungkapan modal intelektual mempengaruhi nilai perusahaan.

\subsection{Populasi dan Sampel}

Populasi penelititan adalah seluruh perusahaan LQ45 yang terdaftar di Bursa Efek Indonesia pada periode 2014 sampai dengan 2016.Penggunaan saham LQ45 berdasarkan alasan lebih likuid diperdagangkan. Sampel penelitian adalah seluruh populasi penelitian.

\subsection{Jenis Data}

Penelitian ini menggunakan data sekunder berupa Laporan Keuangan, Laporan Tahunan, dan data harga saham.Data PMI diperoleh dari Laporan Tahunan yang bersumber dari situs Bursa Efek Indonesia, yaitu www.idx.co.id. Harga saham diperoleh 
dari situs yahoo finance.com.Variabelukuran dewan komisaris, komisaris independen, leverage, dan ukuran perusahaan diperoleh Laporan Keuangan.

\subsection{Definisi dan Pengukuran Variabel}

Variabel penelitian terdiri atas pengungkapan modal intelektual (PMI), ukuran dewan komisaris, komisaris independen, ukuran perusahaan, leverage, dan nilai perusahaan. PMI dilakukan dengan 4 cara sistem kode numerik, yang dikembangkan oleh Guthrie et al. (1999), yaitu 0 apabila item tidak diungkapkan; 1 apabila item diungkapkan dalam bentuk narasi; 2 apabila item diungkapkan dalam bentuk numerik; 3 apabila item diungkapkan dengan nilai moneter. Metode perolehan data PMI menggunakan metode content analysis dengan skema ICD-In yang dikembangkan oleh Ulum (2015) yang merupakan pengembangan dari Guthrie et al. (1999).Metode ini sebelumya dikembangkan oleh Sveiby (1997), kemudian digunakan oleh Puteri dan Chairi, 2016). PMI terdiri dari 36 item yang digolongkan atas tiga kategori utama, yaitu kategori human capital (8 item); structural capital (15 item); relational capital (13 item). Modal intelektual dikuantifikasi dengan skor pengungkapan modal intelektual (SPMI) (Rashid et al., 2012).

$$
S P M I=\left(\sum_{t=1}^{M} d i / M\right) \times 100 \%
$$

Ukuran Dewan Komisaris (BSIZE) adalah jumlah anggota dewan komisaris dalam pengawasan terhadap manajemen. Ukuran dewan komisaris diukur berdasarkan jumlan anggota dewan komisaris dalam perusahaan (Rashid et al., 2012: Puteri dan Chairi, 2016).

Komisaris Independen adalah anggota dewan komisaris yang tidak memiliki hubungan kekerabatan dengan manajemen.Variabel ini diukur dengan persentase jumlah dewan komisaris independen dibandingkan dengan jumlah seluruh dewan komisaris perusahaan.Metode ini sebelumya digunakan oleh Rashid et al., 2012 dan Puteri dan Chairi (2016).

$$
B S I Z E=\frac{\text { Jumlah Dewan Komisaris Independen }}{\text { Total Dewan Komisaris }} \times 100 \%
$$

Ukuran perusahaan adalah asset yang dimiliki oleh perusahaan.Ukuran perusahaan diukur dengan logaritma natural jumlah asset yang dimiliki oleh perusahaan.Leverage adalah tingkat yang menunjukkan sejauh mana perusahaan menggunakan utang atau uang pinjaman dalam operasional perusahaan. Laverage diukur dengan debt to asset ratio (DAR).Nilai perusahaan diukur dengan rasio nilai pasar terhadap nilai buku ekuitas perusahaan. Fama dan French (1992) menemukan bahwa logaritma dari rasio nilai pasar terhadap nilai buku menjadi lebih kuat dan lebih signifikan dalam menjelaskan suatu hubungan dibandingkan hanya nilai pasar dari ekuitas saja dalam menjelaskan pengembalian rata-rata.Lebih jauh lagi, Berk (1995) menyatakan bahwa ukuran rasio nilai pasar terhadap nilai buku lebih baik dibandingkan hanya menggunakan ukuran dari nilai pasar saja. Karena ukuran nilai perusahaan ini, rasio nilai pasar terhadap nilai buku, menunjukkan tingkat kemiringan dan kurtosis yang tinggi, transformasi logaritma natural digunakan untuk mengurangi pengaruh dari nilai ekstrim dan membawa distribusi rasio nilai pasar terhadap nilai buku menjadi lebih dekat kepada normalitas.

\subsection{Analisis Data}

Analisis yang digunakan adalah statistik deskriptif dan analisis regresi. Statistik deskriptif digunakan untuk memberikan deskripsi suatu data dari sisi rata-rata (mean), deviasi standar (standar deviation), dan maksimum-minimum (Ghozali, 2016:19). Analisis regresi digunakan untuk mengetahui pengaruh variable independen pada variable 
dependen. Penelitian ini mengembangan dua model regresi linier, yaitu linier berganda dan regresi linier sederhana. Model regresi pertama dengan regresi linier berganda, menggunakan PMI sebagai variabel dependen, ukuran dewan komisaris (BSIZE), dewan komisaris independen (BIND), ukuran perusahaan (LogSIZE), leverage(LEV). Identifikasi PMI dilakukan dengan four-way numerical coding system yang dikembangkan oleh Guthrie et al. (1999) untuk selanjutnya dikuantifikasi menggunakan Intellectual Capital Disclosure Score (PMIS). Model regresi kedua, dengan regresi linier, digunakan untuk menguji hubungan PMI terhadap Nilai Perusahaan.Dari kedua model regresi ini, tercermin bahwa PMI berperan sebagai variable dependen untuk model pertama sekaligus sebagai variabel independen untuk model kedua. Berikut ini disajikan perumusan kedua model tersebut.

(Model I)

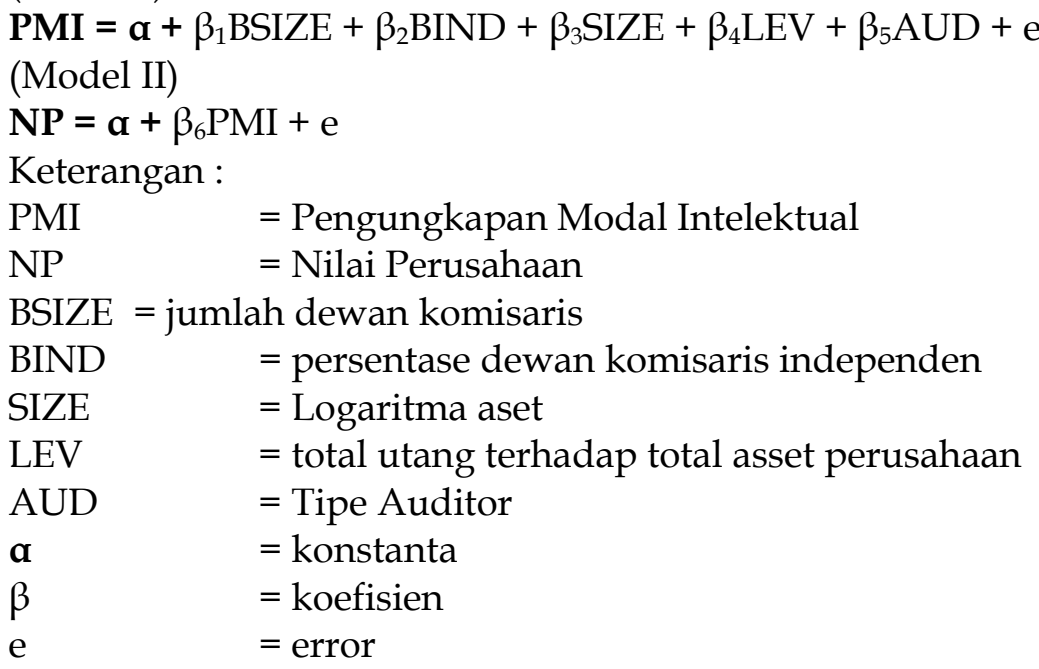

Berdasarkan hasil analisis yang dilakukan dapat diperoleh informasi hasil uji kelayakan model (F), koefisien determinasi (Adjusted $\mathrm{R}^{2}$ ), dan uji hipotesis (uji $\mathrm{t}$ ).

\section{PEMBAHASAN}

\subsection{Hasil Analisis Deskriptif}

Variabel penelitian, meliputi jumlah dewan komisaris (DK), persentase dewan komisaris independen (DKI), ukuran perusahaan (UP), komite audit (KA), pengungkapan modal intelektual (PMI), dan nilai perusahaan (NP). Penelitian ini menghitung nilai minimum, nilai maksimum, rata-rata, dan deviasi standar variable 135 perusahaan sampel penelitian. Tabel 1 menyajikan nilai minimum, nilai maksimum, rata-rata, dan deviasi standar variable penelitian.

Tabel 1. Statistik Deskriptif Variabel Penelitian

\begin{tabular}{crrrrr}
\hline Variabel & $\begin{array}{c}\text { Jumlah } \\
\text { Sampel }\end{array}$ & $\begin{array}{c}\text { Nilai } \\
\text { Minimum }\end{array}$ & $\begin{array}{c}\text { Nilai } \\
\text { Maksimum }\end{array}$ & Rata-rata & Deviasi Standar \\
\hline DK & 135 & 3,00 & 11,00 & 5,64 & 2,00 \\
DKI & 135 & 28,57 & 80,00 & 43,44 & 13,24 \\
UP & 135 & 12,46 & 15,05 & 13,58 & 0,60 \\
LEV & 135 & 0,03 & 0,93 & 0,51 & 0,22 \\
NP & 135 & 0,20 & 82,44 & 4,83 & 10,88 \\
PMI & 135 & 46,88 & 84,38 & 68,84 & 8,00 \\
\hline
\end{tabular}

Sumber : data diolah, 2018 
Variabel DK memiliki nilai rata-rata sebesar 5,64 dengan simpangan baku sebesar 2,00. Hal ini berarti rata-rata ukuran dewan komisaris perusahaan sebanyak 5 sampai 6 orang. Jumlah DK memiliki variasi yang cenderung kecil, yaitu sebesar 2 orang. Nilai minimum untuk jumlah DK sebanyak 3 orang yang dimiliki oleh perusahaan AKRA, CPIN, CTRA, BDMN, ITMG, JSMR, MNCN, PWON, dan SMGR. Nilai maksimum jumlah DK sebanyak 11 orang yang dimiliki oleh perusahaan ASII dan BBRI. Nilai rata-rata variabel DKI sebesar 43,44 dengan simpangan baku sebesar 13,24. Hal ini berarti rata-rata proporsi jumlah komisaris independen dibandingkan dengan jumlah seluruh dewan komisaris adalah 43,44\%. Proporsi DKI memiliki variasi yang cenderung kecil. Nilai minimum untuk proporsi dewan komisaris independen sebesar 28,57\% yang diperoleh perusahaan INTP, sedangkan nilai maksimum sebesar $80,00 \%$ yang diperoleh perusahaan LPKR. Variabel UP diukur dengan logaritma natural jumlah aset perusahaan. Data pada variabel UP berjumlah 135 amatan dengan nilai rata-rata sebesar 13,58 dengan simpangan baku sebesar 0,59 . Hal ini berarti data pada variabel UP memiliki variasi yang cenderung kecil. Nilai minimum untuk UP sebesar 12,46 dimiliki oleh TAXI tahun 2015, sedangkan nilai maksimum sebesar 15,05 diperoleh oleh BBRI tahun 2017. Nilai rata-rata variabel LEV sebesar 0,51 dengan simpangan baku sebesar 0,23. Hal ini berarti rata-rata proporsi utang berbanding aset adalah 51\%.LEV memiliki variasi yang cenderung kecil. Nilai minimum untuk LEV sebesar 3\% yang diperoleh perusahaan HMSP, sedangkan nilai maksimum sebesar 93\% yang diperoleh perusahaan TBIG. Nilai rata-rata variabel NP sebesar 4,83 dengan simpangan baku sebesar 10,87 . Hal ini berarti rata-rata nilai perusahaan yang dukur dari perbandingan harga pasar berbanding nilai buku ekuitas adalah 4,83. NP memiliki variasi yang cenderung besar. Nilai minimum untuk NP sebesar 0,20 yang diperoleh perusahaan ANTM tahun 2015, sedangkan nilai maksimum sebesar 82,44 yang diperoleh perusahaan UNVR tahun 2017. Nilai rata-rata variabel PMI sebesar 68,84 dengan simpangan baku sebesar 8,00. Hal ini berarti rata-rata pengungkapan modal intelektual pada laporan tahunan yang diukur dengan SPMI sebanyak $68,84 \%$ dari nilai maksimum pengungkapan. PMI memiliki variasi yang cenderung kecil. Nilai minimum untuk PMI sebesar 46,88\% yang dilaporkan oleh perusahaan GGRM tahun 2015, sedangkan nilai maksimum sebesar $82,44 \%$ yang diperoleh perusahaan BBRI dan BBNI.

\subsection{Hasil Analisis Regresi}

Analisis regresi linear bertujuan untuk mengetahui adanya pengaruh dan kuatnya pengaruh antara veriabel independen pada variable dependen. Pertama, Penelitian ini bertujuan menguji pengaruh variable penentu pengungkapan modal intelektual (PMI), yaitu jumlah dewan komisaris (DK), proporsi dewan komisaris independen (DKI), ukuran perusahaan (UP), dan leverage (LEV). Kedua, penelitian ini menguji konsekuensi dari pengungkapan modal intelektual (PMI) pada nilai perusahaan (NP). Hasil analisis regresi untuk menguji pengaruh jumlah dewan komisaris (DK), proporsi dewan komisaris independen (DKI), ukuran perusahaan (UP), dan leverage (LEV) pada pengungkapan modal inteletual dapat dilihat di Tabel 2. 
Tabel 2. Hasil Analisis Regresi Linear Berganda Model 1

\begin{tabular}{|c|c|c|c|c|c|}
\hline \multirow[t]{2}{*}{ Veriabel Independen } & \multicolumn{2}{|c|}{ Unstandardized Coefficients } & \multirow{2}{*}{$\begin{array}{c}\text { Standardized } \\
\text { Coefficients }\end{array}$} & \multirow[t]{2}{*}{$\mathrm{t}$} & \multirow[t]{2}{*}{ Sig. } \\
\hline & $B$ & Std. Error & & & \\
\hline$\overline{\text { (Constant) }}$ & 16,119 & 14,014 & & 1,15 & 0,252 \\
\hline DK & 0,750 & 0,299 & 0,188 & 2,51 & 0,013 \\
\hline DKI & 0,105 & 0,044 & 0,174 & 2,37 & 0,019 \\
\hline UP & 2,766 & 1,137 & 0,206 & 2,43 & 0,016 \\
\hline LEV & 12,518 & 2,822 & 0,344 & 4,43 & 0,000 \\
\hline $\bar{F}$ & & 22,523 & & & \\
\hline Sig. F & & 0,000 & & & \\
\hline R Square & & 0,409 & & & \\
\hline Adjusted R Square & & 0,391 & & & \\
\hline
\end{tabular}

Sumber : data diolah, 2018

Tabel 2 melaporkan nilai R Square sebesar 0,409. Nilai ini berarti 40,9\% variasi pengungkapan modal intelektual (PMI) dijelaskan oleh jumlah dewan komisaris (DK), proporsi dewan komisaris independen (DKI), ukuran perusahaan (UP), dan leverage (LEV). Variabel lain menjelaskan 59,1\% variasi pengungkapan modal intelektual. Tabel 4.9 melaporkan nilai $\mathrm{F}$ hitung sebesar 22,253 dengan nilai signifikansi sebesar 0,000. Nilai signifikansi sebesar 0,000 kurang dari a sebesar 0,05. Hal ini berarti model penelitian dapat dipergunakan dan dianalisis lebih lanjut.

Tabel 2 menunjukan jumlah dewan komisaris (DK) berpengaruh positif pada pengungkapan modal intelektual (PMI). Nilai signifikasi (Sig.) sebesar 0,013 lebih kecil dari tingkat signifikansi (a) sebesar 5\% menyimpulkan adanya pengaruh signifikan jumlah dewan komisaris pada pengungkapan modal intelektual. Hasil pengujian ini gagal mendukung pernyataan hipotesis penelitian, jumlah dewan komisaris berpengaruh negatif pada pengungkapan modal intelektual. Hasil penelitian ini menemukan jumlah dewan komisaris berpengaruh positif pada pengungkapan modal intelektual. Semakin banyak jumlah komisaris perusahaan, akan berdampak pada semakin luas pengungkapan modal intelektual yang dilakukan oleh perusahaan kepada publik melalui laporan tahunan. Dewan komisaris bertugas sebagai pengendali tertinggi di perusahaan. Dewan komisaris bertindak mewakili prinsipal bertugas mengendalikan tindakan manajer perusahaan sebagai pihak agen. Pengendalian yang dilakukan oleh dewan komisaris bertujuan memastikan manajer bertindak sesuai dengan kepentingan dewan komisaris. Pengendalian yang dilakukan oleh dewan komisaris akan mengurangi biaya keagenan melalui penekanan kepada manajer untuk mengungkapkan informasi mengenai modal intelektual secara relevan dan akurat (Mahadewi et al, 2013). Hasil penelitian ini mendukung hasil penelitian Romero et al. (2017), Mahadewi et al. (2013), Abeysekera (2010), Allegrini dan Greco (2013), Briano Turrent and Saavedra Garcia (2015), Gisbert dan Navallas, (2013), dan Hidalgo et al. (2011). Penelitian ini menemukan bahwa pengungkapan modal intelektual yang lebih luas pada perusahaan yang memiliki jumlah dewan komisaris relatif banyak. Perusahaan besar akan menghadapi tekanan dari stakeholders yang membutuhkan lebih banyak informasi mengenai perusahaan. Ukuran perusahaan berhubungan dengan ukuran dewan komisaris (Romero et al., 2017). Semakin besar ukuran perusahaan, semakin besar ukuran dewan komisaris. Ukuran akan mempengaruhi efisiensi, efektifitas, dan supervisi dewan komisaris dalam melaksanakan tugas (Hidalgo et al., 2011, Rodrigues et al., 2017) mengenalikan manajemen perusahaan. Pengendalian yang efektif dan efisien serta supervisi yang baik akan mendorong perusahaan untuk melakukan pengungkapan modal intelektual lebih banyak. Jumlah dewan komisaris perusahaan publik di Indonesia diatur oleh Peraturan Otoritas Jasa Keuangan (POJK) Nomor 33/POJK.04/2014.POJK Nomor 33/POJK.04/ 2014 mengharuskan perusahaan publik memiliki dewan komisaris minimal 
dua orang.POJK 55 /POJK.03/2016 tentang Penerapan Tata Kelola Bagi Bank Umum mengharuskan Bank Umum memiliki minimal 3 orang dewan komisaris.Jumlah dewan komisaris yang lebih banyak dasarkan pada beberapa alasan. Pertama, jumlah komisaris yang besar memungkinkan pengendalian yang lebih baik apabila memiliki kompetensi dan pengalaman yang berbeda dan saling melengkapi (Gisbert \& Navallas, 2013; Hidalgo et al., 2011; Rodríguez-Ariza et al., 2014). Kedua, jumlah dewan komisaris yang semakin besar akan meningkatkan proses pengambilan keputusan dan meningkatkan jumlah informasi yang diberikan (Briano Turrent \& Saavedra Garcia; Gisbert \& Navallas, 2013). Ketiga, jumlah dewan komisaris yang lebih besar akan meningkatkan pengendalian dewan komisaris kepada manajemen perusahaan (Al-Moataz \& Hussainey, 2012).

Penelitian ini membuktikan proporsi dewan komisaris independen (DKI) berpengaruh positif pada pengungkapan modal intelektual. Simpulan ini didasarkan pada hasil analisis regresi pada Tabel 2 . Hasil analisis menunjukan nilai unstandardized coefficient beta sebesar 0,105 dan nilai signifikansi (Sig.) sebesar 0,019. Nilai unstandardized coefficient beta positif dan nilai signifikansi lebih kecil daripada a sebesar 0,05, dapat disimpulkan proporsi dewan komisaris independen berpengaruh positif signifikan pada pengungkapan modal intelektual. Hasil pengujian mendukung hipotesis penelitian. Temuan ini mendukung hasil penelitian sebelumnya, seperti Cerbioni dan Parbonetti (2007), Chen dan Jaggi (2000), White et al. (2007) dan Rashid et al (2012). Dewan komisaris independen dibentuk untuk mengawasi dan mensupervisi manajemen perusahaan (Jensen dan Meckling, 1976). Otoritas Jasa Keuangan mengharuskan perusahaan publik yang tercatat di Bursa Efek Indonesia untuk membentuk komisaris Independen yang tertuang dalam POJK Nomor 33/POJK.04/2014 tentang Direksi Dan Dewan Komisaris Emiten Atau Perusahaan Publik. Komisaris Independen adalah anggota dewan komisaris yang berasal dari luar emiten atau perusahaan publik dan memenuhi persyaratan sebagai komisaris independen. POJK Nomor 33/POJK.04/2014 mengatur proporsi dewan komisaris yang harus dimiliki oleh perusahaan, yaitu (1) perusahaan diwajibkan memiliki satu dewan komisaris independen, apabila jumlah dewan komisaris dua orang, (2) apabila jumlah dewan komisaris terdiri lebih dari dua orang anggota, maka jumlah komisaris independen wajib paling kurang tiga puluh persen dari jumlah seluruh anggota dewan komisaris. Kewajiban perusahaan publik yang terdaftar di Bursa Efek Indonesia akan meningkatkan pengendalian dan surpervisi dewan komisaris kepada manajemen perusahaan. Peran komisaris independen dalam meningkatkan pegendalian dan supervisi kepada manajemen perusahaan karena beberapa alasan. Pertama, komisaris independen lebih bertanggung jawab melindungi kepentingan stakeholders (García et al., 2011). Kedua, komisaris independen lebih independen dan objektif dalam menganalisis perilaku manajemen perusahaan (Prado Lorenzo et al., 2009). Ketiga, komisaris independen lebih bertanggung jawab kepada stakeholders (Romero et al., 2017). Peran komisaris independen tersebut akan meningkatkan kualitas dan kuantitas pengungkapan informasi perusahaan kepada publik. Penelitian ini menemukan semakin tinggi persentase komisaris independen dalam dewan komisaris, pengungkapan modal intelektual semakin luas. Semakin tinggi persentase komisaris independen pada dewan komisaris akan meningkatkan peran pengendalian dan supervise dewan komisaris. Dewan komisaris yang memiliki komposisi komisaris independen yang relatif besar akan mendorong manajemen untuk meningkatkan kualitas dan kuantitas informasi modal intelektual perusahaan kepada publik melalui laporan tahunan sebagai bentuk pertanggungjawaban kepada stakeholders.

Hasil analisis regresi pada Tabel 2 mendukung hipotesis penelitian yang menyatakan ukuran perusahaan berpengaruh positif pada pengungkapan modal intelektual. Tabel 2 melaporkan nilai ustandardize coefficient beta positif sebesar 2,766 dengan nilai signifikansi 
sebesar 0,016. Nilai signifikansi lebih kecil dari a sebesar 0,05, sehingga dapat disimpulkan ukuran perusahaan berpengaruh positif signifikan pada pengungkapan modal intelektual. Tiga penjelasan yang dapat diberikan atas temuan tersebut.Pertama, semakin besar perusahaan, semakin besar masalah keagenan perusahaan. Masalah keagenan dapat dikurangi dengan memberikan lebih banyak informasi kepada pemegang saham. Modal intelektual merupakan salah satu informasi penting yang dapat diinformasi kepada pemegang saham perusahaan. Kedua, perusahaan besar umumnya mendapat perhatian dari stakeholders, sehingga praktik pengungkapan informasi seperti pengungkapan modal intelektual akan dilakukan perusahaan untuk mengurangi biaya politis (White et al., 2007). Ketiga, perusahaan besar umumnya mendapat perhatian dari publik sebagai konsekuensi dari kompetisi usaha dan kebutuhan pasar. Pengungkapan informasi, seperti informasi modal intelektual adalah usaha dari perusahaan untuk merealisasi pertanggungjawaban perusahaan publik. Sebaliknya, perusahaan yang lebih kecil tidak akan mengungkapkan informasi modal intelektual yang luas karena akan melemahkan posisinya dalam persaingan usaha. Manajer perusahan kecil mengganggap pengungkapan lebih banyak modal intelektual kepada publik akan membahayakan potensi kompetitif perusahaan (Ulum, 2009; Dewi et al., 2014). Keempat, perusahan besar pada umumnya memiliki lebih banyak bentuk modal intelektual daripada perusahaan kecil sehingga lebih banyak pengungkapan modal intelektual yang dilakukan dalam laporan tahunan (An, 2014). Kelima, perusahaan besar mengeluarkan biaya yang lebih rendah dalam menyusun dan mendesiminasi informasi modal intelektual kepada publik daripada perusahaan kecil, serta perusahaan besar memiliki biaya kompetitif yang lebih rendah yang berhubungan dengan pengungkapan modal intelektual (Meek, Roberts, and Gray, 1995). Hasil penelitian mendukung hasil penelitian sebelumnya, seperti Bozzolan et al. (2003), White et al. (2007), Cerbioni and Parbonetti (2007), Cordazzo (2007), Garcia-Meca et al. (2005), Garcia-Meca and Martinez (2007), Guthrie et al. (2006), Oliveira et al. (2006), Octama (2011), dan Ulum et al, (2012).

Hasil analisis regresi pada Tabel 2 melaporkan nilai unstandardize coefficient dan nilai signifikansi untuk variabel leverage sebesar 12,58 dengan nilai signifikansi sebesar 0,000. Nilai unstandardize coefficient positif dan nilai signifikansi variabel leverage kurang daripada a sebesar 0,05, dapat disimpulkan leverage berpengaruh positif dan signifikan pada pengungkapan modal intelektual. Hasil penelitian mendukung teori keagenan. Perusahaan publik yang memiliki leverage tinggi memiliki masalah keagenan lebih tinggi daripada perusahaan yang memiliki leverage rendah. Perusahaan publik yang memiliki leverage tinggi akan berusaha mengangkapkan lebih banyak informasi secara sukarela kepada publik untuk mengurangi asimetri informasi antara manajemen perusahaan dan kreditor, dan selanjutnya mengurangi kos keagenan (Farag, Meng, \& Mallin, 2015).

Hasil penelitian ini mendukung teori sinyal.Perusahaan dengan sukarela mengungkapkan ke publik informasi modal intelektual yang dimiliki oleh perusahaan untuk menunjukan superioritas kualitas perusahaan sehingga meningkatkan keyakinan kreditor pada operasional perusahaan, dan selanjutnya mendapatkan dukungan keuangan dari kreditor (An et al., 2011). Hasil penelitian ini mendukung penelitian Williams (2001), Oliviera et al. (2006), Singh dan van der Zahn (2007), White et al. (2007), Ulum et al. (2012), dan Rashid et al. (2012) yang menunjukkan adanya hubungan yang signifikan dan positif antara leverage dengan PMI. 
Tabel 3. Hasil Analisis Regresi Linear Sederhana Model 2

\begin{tabular}{|c|c|c|c|c|c|}
\hline \multirow[t]{2}{*}{ Veriabel Independen } & \multicolumn{2}{|c|}{ Unstandardized Coefficients } & \multirow{2}{*}{$\begin{array}{c}\text { Standardized } \\
\text { Coefficients } \\
\text { Beta }\end{array}$} & \multirow[t]{2}{*}{$\mathrm{T}$} & \multirow[t]{2}{*}{ Sig. } \\
\hline & $B$ & Std. Error & & & \\
\hline$\overline{\text { (Constant) }}$ & $-13,572$ & 8,007 & & $-1,695$ & 0,092 \\
\hline PMI & 0,267 & 0,116 & 0,197 & 2,314 & 0,022 \\
\hline R Square & & 0,027 & & & \\
\hline Adjusted R Square & & 0,020 & & & \\
\hline
\end{tabular}

Sumber : data diolah, 2018

Tabel 3. melaporkan hasil analisis regresi linear sederhana model 2, yaitu pengungkapan modal intelektual sebagai prediktor dari nilai perusahaan. Hasil analisis regresi sederhana melaporkan nilai unstandardize coefficient dan nilai signifikansi untuk variabel PMI sebesar 0,267 dengan nilai signifikansi sebesar 0,022. Nilai unstandardize coefficient positif dan nilai signifikansi variabel PMI kurang daripada a sebesar 0,05, dapat disimpulkan PMI berpengaruh positif dan signifikan pada Nilai Perusahaan. Perusahaan yang mengungkapkan modal intelektual yang lebih luas, dinilai lebih tinggi oleh investor. Pengungkapan modal intelektual merupakan pengungkapan surarela yang dilakukan oleh manajemen perusahaan. Pengungkapan ini berdampak pada penilaian yang lebih tinggi oleh investor atas perusahaan. Hasil ini diperoleh karena informasi modal merupakan salah satu informasi penting yang digunakan oleh investor untuk menilai perusahaan. Modal intelelektual menjadi informasi penting pada era informasi dan pengetahuan untuk pertumbuhan perusahaan. Pada era infomasi, basis pertumbuhan perusahaan beralih dari sumberdaya berujud menjadi tidak berujud, yaitu modal intelektual (Guthrie et al., 1999). Modal intelektual merupakan sumber daya penting dalam mendapatkan keunggulan kompetitif yang berkelanjutan (Hayton, 2005), menciptakan nilai dan meningkatkan kinerja dan pertumbuhan perusahaan (Ishak et al., 2016). Hal ini menunjukan telah terjadi peralihan ke ekonomi berbasis pengetahuan yang memicu peran penting modal intelektual dalam penciptaan nilai perusahaan (Holland, 2003).Peran penting modal intelektual meningkatkan asimetri informasi antara investor atau calon investor di pasar modal dan manajemen perusahaan. Teori sinyal menyatakan manajemen perusahaan akan berusaha untuk memberi informasi kepada investor di pasar modal dan stakeholder lain melalui pengungkapan sukarela (Oliviera et al., 2006). Pengungkapan modal intelektual secara sukarela akan mengurangi asimetri informasi antara manajer dan investor di pasar modal akan meningkatkan nilai perusahaan.

\section{SIMPULAN DAN SARAN}

\subsection{Simpulan}

Penelitian ini bertujuan meneliti faktor penentu dan konsekuensi dari pengungkapan modal intelektual pada perusahaan LQ45 yang terdaftar di Bursa Efek Indonesia. Pengungkapan modal intektual pada perusahaan LQ45 di Bursa Efek Indonesia rata-rata 68,84\% dari 135 item pengungkapan modal intelektual. Jumlah pengungkapan terbesar sebesar 84,38\%, sedangkan jumlah pengkapan terendah sebesar 46,88\%. Variasi pengungkapan ini dapat dijelaskan oleh jumlah dewan komisaris, proporsi dewan komisaris, ukuran perusahaan, dan leverage.

Penelitian ini menemukan ukuran perusahaan dan leverage terbukti berpengaruh positif pada pengungkapan modal intelektual. Hasil penelitian ini membuktikan semakin banyak jumlah dewan komisaris, semakin luas pengungkapan modal intelektual yang diungkapkan oleh perusahaan. Hasil penelitian ini menemukan proporsi dewan komisaris 
independen dalam dewan komisaris perusahaan berpengaruh positif pada pengungkapan modal intelektual. Adanya pengaruh positif jumlah dewan komisaris dan proporsi dewan misais independen pada pengungkapan modal intelektual memberikan dukungan empiris teori keagenan, serta peraturan yang mengatur pembentukan dewan komisaris perusahaan yang terdaftar di Bursa Efek Indonesia, yaitu POJK Nomor 33/POJK.04/ 2014 tentang Direksi Dan Dewan Komisaris Emiten Atau Perusahaan Publik.

Penelitian ini menemukan pengaruh positif pengungkapan modal intelektual pada nilai perusahaan.Semakin luas pengungkapan modal intelektual, semakin tinggi nilai perusahaan.Pengungkapan modal intelektual merupakan pengungkapan sukarela perusahaan yang dapat digunakan sebagai sinyal oleh manajemen perusahaan kepada investor di pasar modal.

\subsection{Saran}

Hasil penelitian ini memberikan saran bagi investor dan manajemen perusahaan. Investor dapat memperhatikan pengungkapan modal intelektual untuk mengambil keputusan investasi di pasar modal. Investor dapat berinvestasi ada perusahaan dengan pengungkapan modal intelektual yang relative lebih luas, karena pengungkapan modal intektual berpengaruh positif pada nilai perusahaan.Manajemen perusahaan juga perlu memperhatikan pengungkapan modal intelektual yang dimiliki oleh perusahaan. Pengungkapan modal yang luas berdapak pada nilai perusahaan yang tinggi.

Penelitian ini memberikan saran untuk peneliti selanjutnya. Pertama, penelitian ini menggunakan perusahaan yang terdaftar di LQ45 sebagai sampel penelitian, sehingga membatasi hasil penelitian. Penelitian selanjutnya diharapkan menggunakan sampel yang lebih luas untuk meningkatkan generalisasi hasil penelitian. Kedua, pengungkapan modal intelektual bervariasi sesuai dengan industri, sehinga industri juga dapat dipergunakan sebagai sebagai penentu pengungkapan modal intelektual.

\section{DAFTAR PUSTAKA}

Abdolmohammadi, M. J. (2005). Intellectual capital disclosure and market capitalization. Intellectual Capital, 397-416.

Abeysekera, I. (2010). The influence of board size on intellectual capital disclosure by Kenyan listed firms. Journal Of Intellectual Capital Volume 11, Issue 4 , 504-518.

Allegrini, M. dan G. Greco, (2013). Corporate boards, audit committees and voluntary disclosure: evidence from Italian Listed Companies Journal of Management $\mathcal{E}$ Governance, Springer; Accademia Italiana di Economia Aziendale (AIDEA). Vol. 17(1), 187216

Al-Moataz, E., \& Hussainey, K. (2012).Determinants of corporate governance disclosure in Saudi companies. Journal of Economics and Management, 5(1), 52-84

An, Y dan Harun H. (2014). Determinants Of Intellectual Capital Disclosure By Chinese Companies: An Empirical Investigation. Working Paper. Ocean University of China.

Anam, O., Fatima, A., \& Majdi, A. (2011). Effects of Intellectual Capital Information Disclosed in Annual Reports on Market Capitalization : Evidence from Bursa Malaysia. Journal of Human Resources Costing and Accounting, 85-101.

Berk, J., (1995). A critique of size related anomalies. Review of Financial Studies 8, 275-286.

Bozzolan, S., Favotto, F., \& Ricceri, F. (2003). Italian Annual Intellectual Capital Disclosure: An Emipical Analysis. Journal of Intellectual Capital, 543-558.

Briano Turrent, G. C. dan Saavedra Garcia, M. L. (2015). The composition of the board and ownership structure as explanatory factors of transparency in corporate governance 
in Latin America: Evidence from listed companies in Argentina, Brazil, Chile and Mexico. Estudios Gerenciales, 31(136), 275-286.

Briano Turrent, G. C., \& Saavedra Garcia, M. L. (2015). The composition of the board and ownership structure as explanatory factors of transparency in corporate governance in Latin America: Evidence from listed companies in Argentina, Brazil, Chile and Mexico. Estudios Gerenciales, 31(136), 275-286.

Bruggen, A., \& Dao, M. (2009). Determinants of Intellectual Capital Disclosure : evidence from Australia. Management Decision, 233-245.

Cerbioni, F., \& Parbonetti, A. (2007). Exploring The effects of Corporate Governance on Intellectual Capital Disclosure: An Analysis of European Biotechnology Companies. European Accountig Review, 791-826.

Chen , C., \& Jaggi, B. (2000). Association Between Independent Non-Executive Directors, Family Control, and Financial Disclosure in Hong Kong. Journal of Accounting and Public Policy, 285-310.

Cordazzo, M. (2007). Intangibles and Italian IPO Prospectuses: A Disclosure Analysis. Journal of Intellectual Capital, 288-305.

Dewi, K., Young, M., dan Sundari, R. (2014). Firm characteristics and intellectual capital disclosure on service companies listed in Indonesia stock exchange period 2008-2012. Merit Research Journal of Accounting, Auditing, Economics and Finance Vol. 2(2) pp. 02203

Edvinsson, L., and Sullivan, P. (1996). Developing a model for managing intellectual capital. European Management Journal, Vol. 14 No. 4.

Fama, E. (1980). Agency Problem and Theory of The Firm. Journal of Political Economy, 288307.

Fama, E., \& Jensen, M. (1983). Separation of Ownership and Control. Journal of Law and Economics, 301-326.

Fama, Eugene \& French, K.R, (1992).The Cross Section of Expected Stock Returns. The Journal of Finance, 67, 2, 427.

Farag, H., Q. Meng, \& C. Mallin, (2015) The social, environmental and ethical performance of Chinese companies: Evidence from the Shanghai Stock Exchange. International Review of Financial Analysis, Vol. 42, 53-63.

Ferreira, A. (2012). Factors influencing intellectual capital disclosure by Portugese Companies. International Journal of Accounting and Financial Review, 278-298.

Francis, J. \& K. Schipper., (1999). "Have Financial Statements Lost Their Relevance?" Journal of Accounting Research (Autumn), 319 - 352.

Garcia-Meca, E., \& Martinez, I. (2007). The Use of Intellectual Capital Informatin on Investment Decision: An Empirical Study Using Analyst Report. The International Journal of Accounting, 57-81.

Garcia-Meca, E., Parra, I., Larran, M., \& Martinez, I. (2005). The Explanatory Factors of Intellectual Capital Disclosure to Financial Analyst. European Accounting Review, 6394.

García-Sánchez, I. M., Rodríguez Dominguez, L., \& Gallego Álvarez, I. (2011). Corporate governance and strategic information on the internet: A study of Spanish listed companies. Accounting, Auditing \& Accountability Journal, 24(4), 471-501.

Ghozali, Imam. 2016. Aplikasi Analisis Multivariate dengan Program IBM SPSS23. Semarang: Badan Penerbit Universitas Diponogoro.

Gisbert, A., \& Navallas, B. (2013). The association between voluntary disclosure and corporate governance in the presence of severe agency conflicts.Advances in Accounting, 29(2), 286-298. 
Gordon, L.A., M. P. Loeb, T. Sohail. (2010). Market Value of Voluntary Disclosures Concerning Information Security.Management Information Systems Quarterly 34, 2, 567-594.

Guthrie, J., Petty, R., \& Ricceri, F. (2006). The Voluntary Reporting of Intellectual Capital: Comparing Evidence from Hong Kong and Australia. Journal of Intellectual Capital, 254-271.

Guthrie, J., Petty, R., Ferrier, F., \& Wells, R. (1999). There is no Accounting for Intellectual Capital in Australia : A Review of Annual reporting Practices and Ther Inernal Measurement of Intangibles. OECD Symposium on Measuring and Reporting of Intellectual Capital. Amsterdam.

Hayton, J.C. (2005). Competing In The Economy: The Effect Of Intellectual Capital On Corporate Entrepreneurship In High-Technology New Ventures. RED Management, Vol. 35, pp. 137-154.

Hidalgo, R. L., García-Meca, E., \& Martínez, I. (2011).Corporate governance and intellectual capital disclosure. Journal of Business Ethics, 100(3), 483-495.

Holland, J. (2003). Intellectual capital and the capital market-organisation and competence. Accounting, Auditing $\mathcal{E}$ Accountability Journal, Volume 16, Issue 1, 39-48, https://doi.org/10.1108/09513570310464264.

Ishak, R., R.A. Bakar, dan H.Kamardin. (2016). Intellectual Capital Disclosure and Firm Governance: Malaysian Evidence. The Social Science 11 (Special Issue 6). 7224-7229.

Jensen, M.C. and Meckling, W.H. (1976). Theory of the firm: managerial behavior, agency costs and ownership structure. Journal of Finance Economics, Vol. 3, October, pp. 30560.

Kamath, G.B. (2007). The Intellectual Capital Performance of Indian Banking Sector. Journal of Intellectual Capital. Vol 8, No.1, pp 96-123

Mahadewi, I N. K. A. Mahaputra, dan N.N.A. Suryandari (2013). Pengaruh Dewan Komisaris Dan Komite Audit Pada Pengungkapan Modal Intelektual Perusahaan Yang Go Public Di Bursa Efek Indonesia. Simposium Nasional Akuntansi Vokasi ke-2 Politeknik Negeri Bali, 17 - 18 Mei 2013.

Marr Bernard, Dina Gray and Andy Neely, (2003), "Why do firms measure their intellectual capital?", Journal of Intellectual Capital, Vol. 4 No. 4, pp.441-464

Meek, G. K, Roberts, C. B., \& Gray, S. J. (1995). Factors influencing voluntary annual report disclosures by US, UK and continental European multinational corporations. Journal of International Business Studies. Third Quarter. p555-572.

Melani, E. (2016). Pengaruh Tidak Langsung Human Capital Melalui Elemen Intellectual Capital Terhadap Kinerja Perusahaan. Simposium Nasional Akuntansi Xix, Lampung.

Neysi, S.H., S. Mazhraeh, dan Z. Mauzavi. (2012). The Importance of Intellectual Capital Disclosure. International Journal of Business and Social Science Vol. 3, No. 15. Pp. 307310.

Octama, M. I. (2011). Analisis Faktor-Faktor Penentu Intellectual Capital Disclosure Terhadap Return Saham. Semarang: Universitas Diponegoro.

Oliviera, L., Rodrigues, L., dan Craig, R. (2006). Firm Specific Determinants on Intangibles Reporting Evidence from The Portugese Stock Market. Journal of Human Resources Costing and Accounting, 11-33.

Peraturan Otoritas Jasa Keuangan (POJK) Nomor 33/POJK.04/2014 tentang Direksi Dan Dewan Komisaris Emiten Atau Perusahaan Publik. 
Prado Lorenzo, J. M., García Sanchez, I. M. \& Gallego-Álvarez, I. (2009). Características del consejo de administración e información en materia de responsabilidad social corporativa.Revista Española de Financiación y Contabilidad, 38(141), 107-135.

Purnomosidhi, B. (2005). Analisis Empiris Terhadap Determinan Praktik Pengungkapan Modal Intelektual pada Perusahaan Publik BEJ.

Puteri, I.N.I. dan A. Chairi. (2016). Anteseden dan Konsekuensi Intellectual Capital Disclosure. Simposium Nasional Akuntansi XIX, Lampung

Ramanauskaite, A. dan M. R. Laginauskaite. (2014). Disclosure On Intellectual Capital In Annual Reports Of Nasdaq Omx Baltic-Listed Companies. Ekonomika, Vol. 93, No. 4, pp. 135-156.

Rashid, A., Ibrahim, M., Othman, R., \& See, F. K. (2012). IC Disclosure in IPO Prospectuses: Evidence From Malaysia. Journal of Intellectual Capital, 57-80.

Rodrigues, L. L., F.T.Romero, R.Craig. (2017). Corporate governance and intellectual capital reporting in a period of financial crisis: evidence from Portugal.

Romero, F.T., J. F. F. E. Araujo dan M. L. Emmendoerfer. (2017). Corporate governance mechanisms and intellectual capital. Review of Business Management, São Paulo.Vol. 19, No. 65 , p. 394-414.

Singh, I., \& Van der Zahn.(2008). Determinants of Intellectual Capital Disclosure in Prospectuses of Initial Public Offerings.Accounting and Bussiness Research, 409-431.

Solitander, M. (2011). When Sharing Becomes A Liability: An Intellectual Capital Approach To Describing The Dichotomy Of Knowledge Protection Versus Sharing In Intra- And Interorganizational Relationships. PhD thesis. Hanken School of Economics.

Stahle, P. dan Stahle, S. (2006) Intellectual capital and national competitiveness: Conceptual and methodological challenges. In: Bounfour, A. (ed.). Capital Immateriel, Connaisance et Performance. Paris, L'Harmattan.

Sugiyono, 2014.Metode Penelitian Bisnis. Bandung : CV. Alfabeta.

Sveiby, K. (1998). Intellectual Capital: Thinking Ahead. Australian CPA, 18-22.

Ulum, I. (2015). Intellectual Capital: Model Pengukuran, Framework Pengungkapan \& Kinerja Organisasi. Malang: Universitas Muhammadiyah.

Ulum, I., Suprapti, E., \& Ariestyowati.(2012). Pengaruh Karakteristik Perusahaan Terhadap Praktik Pengungkapan Intellectual Capital dalam Laporan Tahunan Perusahaan Publik di Indonesia.Jurnal Profita, Komunikasi Ilmiah Akuntansi dan Perpajakan, 10-16.

Utomo, A. I. (2015). Faktor-Faktor yang Mempengaruhi Pengungkapan Modal Intelektual dan Dampaknya terhadap Nilai Perusahaan. Semarang: Universitas Diponegoro.

White , G., Lee, A., \& Tower, G. (2007). Drivers of Voluntary Intellectual capital Disclosure in Listed Biotechnology Companies.Intellectual Capital, 517-537.

Widarjono, A. (2010). Analisis Statistika Multivariat Terapan. Yogyakarta: UPP STIM YKPN.

William, S.M. (2000), "Is intellectual capital performance and disclosure related?",Journal of Intellectual Capital, Vol. 2. No. 3, pp. 192-203. 